\title{
Biochemical investigation of the subretinal fluid
}

\author{
L. M. AKHMETEli, B. S. KaSAVina, and G. A. Petropavlovskaja \\ Helmholtz Institute for Research on Eye Diseases, Moscow \\ (Director: K. V. Trutneva)
}

In the study of the pathogenesis of detachment of the retina an important place is occupied by biochemical research on the subretinal fluid (SRF).

According to current theories of pathogenesis, tears are considered to be the main factor in the development of retinal detachment. The liquid part of the vitreous body penetrates through the tear into the space behind the retina and produces a detachment. If this theory is correct, the biochemical composition of the subretinal fluid should be very similar to the composition of the vitreous body. If, on the other hand, blood elements are discovered, this could be taken as indicating dysfunction of the choroidal capillaries.

It would seem that SRF contains components characteristic both of the vitreous body and of the blood.

Most biochemical research workers have studied the protein composition of the SRF. Particular attention has been paid to inter-relationships between the duration of the detachment and the level of protein in the SRF. Some authors (Magitot and Lenoir, 1932; Arruga, 1933; Weve and Fischer, 1940), who link an increase in the amount of total protein in the SRF with the length of time for which the detachment has been in existence, have assigned the greatest importance in the formation of the SRF to transudation from the vascular bed. Others (Schenk, Formanek, and Förster, 1961, I962; Sachsenweger, Gassler, and Hentsch, I964) have found no correlation between the level of protein in the SRF and the duration of the detachment, and have discovered a high protein content even in very recent detachments.

The results of electrophoretic studies are also contradictory. Thus, Kuzina (1968), on the basis of electrophoretic findings, believed that the SRF was similar in composition to the vitreous body. But according to the findings of Dorello (1956) and Smith and Douty (1960), a specimen of SRF with a high content of protein is similar to a sample of human blood plasma in that it contains the same five components (albumin, alpha ${ }_{1}$, alpha ${ }_{2}$, beta, and gamma globulins).

Address for reprints: Dr. L. M. Akhmeteli, C/o. Division of NCD, WHO, Avenue Appia, 1211 Geneva 27, Switzerland
The results of immunochemical studies are also contradictory. Fojudzki and Kaluzny (1969), who studied the subretinal fluid in idiopathic retinal detachment by immunoelectrophoresis, found that it contained components of blood serum protein. When they used the modification made by Scheidegger (r 955) of the method of Grabar and Williams (1953) they failed to find vitreous body protein, although they believed that it might be present.

Using the same method, Chignell, Carruthers, and Rahi (197I) have demonstrated that the subretinal fluid tends to become more like normal serum the greater the duration of the detachment.

However, one of the fractions which is always present in normal serum (IgM) was not found in any of the cases studied, even those of long duration in which repeated operations had been carried out. The authors believed that this indicated that the capillary endothelium and Bruch's membrane were of limited permeability even in such cases, since in no instance did the subretinal fluid have the protein characteristics of a true exudate.

Using the same method for their immunochemical studies of the vitreous body in human beings and cattle, Cooper, Halbert, and Manski (1963) found large amounts of serum protein. They also found tissue antigens in the human vitreous body that were unconnected with serum. This suggested that the soluble vitreous body antigens are not entirely derived from blood plasma. Analysis of the subretinal fluid of patients with idiopathic detachment revealed the presence of vitreous body components. The authors believed that, if normal human vitreous body contained a large amount of serum protein, the presence of such protein in the subretinal fluid did not indicate that it came from blood, while on the other hand discovery of specific vitreous body protein in the subretinal fluid showed that the vitreous body had something to do with the formation of the fluid. Thus the vitreous body is a component of the subretinal fluid and therefore plays a significant role in the formation and development of idiopathic retinal detachment.

Studies of other components in the SRF have been few. Information on the content of mucopolysaccharides (glucosamine glucans) in the SRF is limited. 
Biochemical study of the SRF fails to attract sufficient attention, partly because of the contradictory nature of the findings and their inapplicability to practical purposes and partly because of the ever wider use of successful surgery without drainage.

Meanwhile, quite often, even the most skilful surgery fails to re-attach the retina and restore the sight.

We therefore decided to study the biochemical findings from a somewhat different point of view. Since the formation of subretinal fluid is inseparable from the concept of retinal detachment, we tried to establish the relationship between the biochemical properties of the SRF and the clinical appearances of retinal detachment and to elucidate the significance of particular biochemical components as indicators of the nature of the retinal detachment. It was also proposed to compare the biochemistry of the SRF with the electrophysiology of the retina and the pathogenesis of retinal detachment.

\section{Material and methods}

\section{$S R F$ and blood studies}

Subretinal fluid was taken during surgery at the point of the greatest projection of the detached retina. Usually a U-shaped suture was made $14 \mathrm{~mm}$. from the limbus, inside which a small incision was made in the sclera down to the tunica vasculosa.

The tunica vasculosa was moved aside with a blunt needle fixed in a 1 or $2 \mathrm{~g}$. dry syringe, and the subretinal fluid was slowly drawn into the syringe by using the plunger without deep penetration into the subretinal space. The suture was then knotted and diathermal coagulation carried out round it. No clinical complications were observed.

Specimens of SRF with an admixture of blood were not examined. For comparative evaluation of the SRF some biochemical components were examined in the peripheral blood.

Biochemical methods of investigating the SRF and the blood included determination of total protein by refractometry and by Lowry's method (Lowry, Rosebrough, Farr, and Randall, 1951); determination of protein fractions by paper electrophoresis and disc electrophoresis in acrylamide gel; determination of sialic acids by the method of Svennerholm (1957); measurement of total hexosamines by the method of Rondle and Morgan (1955); and qualitative separation of the hexosamines by the method of Gardell (1953). The investigations were carried out on 121 specimens of SRF from I 14 patients with retinal detachment.

\section{Electrophysiology}

Among the methods used was determination of the threshold electrical sensitivity of the retina by the method of Semenovskaja and Bogoslovskij (1960).

\section{Clinical features of retinal detachment}

A detailed study was made of I 14 patients. Changes in the fundus oculi (degeneration of the retina, height and extent of detachment, number, shape, and site of tears), in the vitreous body, and in the crystalline lens of the affected eye were studied together with the condition of "paired" eyes.

The patients were women aged from 16 to 74 years and the duration of the detachment ranged from I week to 7 years. 66 patients $\left(57^{\circ} 9\right.$ per cent.) were myopic, the refraction being 3 to $6 \mathrm{D}$ in $34^{\circ} 8$ per cent. and above I $2 \mathrm{D}$ in $27^{\circ} 2$ per cent.

The detachment occurred in aphakic eyes in twelve patients ( $10^{\circ} 5$ per cent.), after injury in eleven $\left(9^{\circ} 6\right.$ per cent.), with senile degeneration of the retina in 22 ( 19.3 per cent.), with chorio-retinitis of tubercular origin in two ( 1.8 per cent.), and in combination with Marfan's syndrome in one (0.9 per cent.). Most patients had severe forms of the disease: total recessive detachments with giant atypical tears; multiple tears in various areas of the fundus oculi; tears in the central zone; extensive degenerative changes in the retina (with the appearance of snails' tracks) and vitreous body; and marked pathology of the lens (extensive opacities, aphakia).

The detachment was bilateral in 27 patients (24 per cent.). No retinal tears could be seen in 23 patients (20 per cent.).

\section{Results}

The total protein was determined by refractometry, which requires only minimum quantities of SRF, on all the fluid specimens obtained (12 I).

The protein content ranged from $0 \cdot 2$ to $10.6 \mathrm{~g}$. per cent. To compare the level of protein in the SRF with the clinical course of the retinal detachment and the outcome of surgical treatment, the patients were arranged in increasing order of concentration of protein in the following three groups:

I: Total protein not exceeding I g. per cent.- 38 patients (40 eyes).

II: Total protein from I to $3 \mathrm{~g}$. per cent.-38 patients ( 38 eyes).

III: Over 3 g. per cent.-4I patients (43 eyes).

\section{Type and severity of detachment}

A comparative evaluation of the clinical condition revealed considerable differences between these groups :

I. In those with the lowest protein content the retina proved least damaged. Detachments predominated which occupied one or two quadrants (the number of total detachments was very small); there were flat and shallow detachments, single tears, and retinodialysis. The degenerative lesions were slight.

II. Total and subtotal detachments were more frequent and tears were multiple and indeterminate, while the degenerative changes were more marked. III. Total and subtotal steep blister-like detachments predominated, and in some patients they were funnelshaped. Opercular tears and holes predominated. The number of detachments in which no tear could be 
Table I Extent of detachment in I 2 I eyes

\begin{tabular}{rllllllll}
\hline \multirow{2}{*}{ Group } & No. of eyes & \multicolumn{5}{l}{ Extent of detachment } \\
\cline { 4 - 7 } & & & I/4 & I/2 & $3 / 4$ & Subtotal & Total \\
\cline { 4 - 7 } & & & & & & & & \\
II & 40 & 9 & I I & 5 & 6 & 9 \\
II & 38 & I & 5 & 3 & 7 & 22 \\
III & 43 & - & 7 & 4 & 7 & 25 \\
\hline
\end{tabular}

Table II Presence and number of tears in 121 eyes

\begin{tabular}{|c|c|c|c|c|c|c|}
\hline \multirow[t]{2}{*}{ Group } & \multirow[t]{2}{*}{ No. of eyes } & \multicolumn{5}{|c|}{ No. of tears } \\
\hline & & $\mathbf{I}$ & 2 & 3 & Multiple & Indeterminate \\
\hline I & 40 & 26 & 6 & 2 & 5 & I \\
\hline II & $3^{8}$ & 15 & 3 & 2 & 12 & 6 \\
\hline III & 43 & 17 & 4 & 2 & 4 & I 6 \\
\hline
\end{tabular}

seen (as a result of the muddiness of the surrounding tissue) was greatest in Group III. Gross changes were found in the retina (significant degeneration and major folds and scars).

Tables I, II, III show the extent of retinal detachment and the number and types of tears in each of the three groups.

\section{Lens damage}

There was also a close relationship between the content of protein in the SRF and the extent of changes in the crystalline lens.
Causes of detachment

Almost all the patients in whom detachment had been caused by injury were in Group I, whereas patients with complicated cataract and aphakia were concentrated in Group III.

\section{Myopia}

No direct relationship was discernible between the level of protein in the SRF and the degree of myopia.

\section{Duration of detachment (Table IV)}

Bearing in mind the contradictory nature of the results reported in the literature regarding the interrelationship between the duration of the detachment and the SRF protein level, the data were assessed from this point of view. In Group I as compared with Group III there was a predominance of patients with detachments less than 3 months old $(\mathrm{P}<0.01)$, whereas long-standing detachments predominated among patients in Group II $\left(\mathrm{P}=\mathrm{O}^{\circ} \cdot 05-0.02\right)$. In some patients, however, the content of protein in the SRF did not correspond to the duration of the detachment even when this had been determined quite precisely.

\section{Surgery}

Out of forty operated eyes in patients in Group I, complete re-attachment was obtained in thirty cases, whereas among patients in Group III only sixteen successful results were obtained out of 43 operated eyes. Some indicators of the course of retinal detachment in the three groups are given in Table $\mathrm{V}$ (overleaf).

Table III Type of tear in 80 eyes with marked tears

\begin{tabular}{|c|c|c|c|c|c|c|}
\hline \multirow[t]{2}{*}{ Group } & \multirow{2}{*}{$\begin{array}{l}\text { No. of eyes } \\
\text { with marked forms } \\
\text { of tear }\end{array}$} & \multicolumn{5}{|c|}{ Type of tear } \\
\hline & & Hole & Opercular & $\begin{array}{l}\text { Retino- } \\
\text { dialysis }\end{array}$ & Valve/hole & Single \\
\hline I & 33 & 4 & 8 & 14 & 4 & $\begin{array}{l}\text { I-valve, hole, } \\
\text { retinodialysis } \\
\text { I-valve } \\
\text { I-atypical }\end{array}$ \\
\hline II & 25 & 13 & 7 & I & 2 & $\begin{array}{l}\text { I-slit-like, hole } \\
\text { I-slit-like }\end{array}$ \\
\hline III & 22 & 7 & 8 & 2 & 2 & $\begin{array}{l}\text { I-atypical } \\
\text { I-retinodialysis, } \\
\text { hole, slit-like } \\
\text { I-retinodialysis, } \\
\text { hole }\end{array}$ \\
\hline
\end{tabular}


Table IV Total protein in the subretinal fuid compared with the duration of detachment in I 2 I eyes

\begin{tabular}{|c|c|c|c|c|c|c|c|c|}
\hline \multicolumn{3}{|c|}{ Group I (40 eyes) } & \multicolumn{3}{|c|}{ Group II (38 eyes) } & \multicolumn{3}{|c|}{ Group III (43 eyes) } \\
\hline $\begin{array}{l}\text { Serial } \\
\text { no. }\end{array}$ & $\begin{array}{l}\text { Total protein } \\
\text { (g. per cent.) }\end{array}$ & $\begin{array}{l}\text { Duration of } \\
\text { detachment } \\
\text { (mths) }\end{array}$ & $\begin{array}{l}\text { Serial } \\
\text { no. }\end{array}$ & $\begin{array}{l}\text { Total protein } \\
\text { (g. per cent. })\end{array}$ & $\begin{array}{l}\text { Duration of } \\
\text { detachment } \\
\text { (mths) }\end{array}$ & $\begin{array}{l}\text { Serial } \\
\text { no. }\end{array}$ & $\begin{array}{l}\text { Total protein } \\
\text { (g. per cent. })\end{array}$ & $\begin{array}{l}\text { Duration of } \\
\text { detachment } \\
\text { (mths) }\end{array}$ \\
\hline I & $0 \cdot 20$ & 4 & $4^{I}$ & $I \cdot 08$ & $?$ & 79 & $3 \cdot 06$ & 3 \\
\hline 2 & $0 \cdot 20$ & I & $4^{2}$ & $1 \cdot 30$ & 9 & 80 & $3 \cdot 06$ & $2 \frac{1}{2}$ \\
\hline 3 & 0.20 & 3 & 43 & $I \cdot 30$ & 7 & 81 & $3 \cdot 06$ & 2 \\
\hline 4 & $0 \cdot 20$ & 2 & 44 & $I \cdot 30$ & 6 & 82 & $3 \cdot 50$ & 5 \\
\hline 5 & $0 \cdot 20$ & 2 & 45 & $1 \cdot 30$ & 4 & 83 & $3.5^{\circ}$ & 3 \\
\hline 6 & $0 \cdot 20$ & 12 & 46 & $1 \cdot 30$ & I & 84 & $3 \cdot 50$ & $I \frac{1}{2}$ \\
\hline 7 & $0 \cdot 20$ & $2 \frac{1}{2}$ & 47 & $1 \cdot 30$ & 4 & 85 & $3 \cdot 50$ & $I \frac{1}{2}$ \\
\hline 8 & $0 \cdot 20$ & 12 & 48 & $1 \cdot 30$ & $2 \frac{1}{2}$ & 86 & 3.50 & 7 \\
\hline 9 & $0 \cdot 20$ & $\mathrm{I} \frac{1}{2}$ & 49 & $1 \cdot 30$ & $4^{2}$ & 87 & $3 \cdot 72$ & 7 \\
\hline 10 & $0 \cdot 20$ & I & 50 & $1 \cdot 30$ & I & 88 & $3 \cdot 94$ & $2 \frac{1}{2}$ \\
\hline I I & $0 \cdot 20$ & 10 & $5^{I}$ & $1 \cdot 52$ & 20 & 89 & $4 \cdot 16$ & 9 \\
\hline 12 & $0 \cdot 20$ & 4 & $5^{2}$ & $I \cdot 52$ & 14 & 90 & $4^{\cdot 16}$ & 48 \\
\hline 13 & $0 \cdot 20$ & I I & 53 & $1 \cdot 52$ & 2 & $9^{I}$ & $4 \cdot 3^{8}$ & 5 \\
\hline 14 & 0.20 & I $\frac{1}{2}$ & 54 & $I \cdot 74$ & 6 & $9^{2}$ & $4 \cdot 3^{8}$ & 13 \\
\hline 15 & $0 \cdot 20$ & $0 \frac{1}{2}$ & 55 & $I \cdot 74$ & 2 & 93 & $4^{6} 60$ & I I \\
\hline 16 & 0.20 & I & 56 & $\mathrm{I} \cdot 74$ & I & 94 & $4 \cdot 60$ & $4 \frac{1}{2}$ \\
\hline 17 & $0 \cdot 20$ & I $\frac{1}{2}$ & 57 & $\mathrm{I} \cdot 74$ & 4 & 95 & $4^{\cdot 8 I}$ & 6 \\
\hline 18 & 0.20 & 2 & $5^{8}$ & $\mathrm{I} \cdot 74$ & I & 96 & $4 \cdot 8 \mathrm{I}$ & 3 \\
\hline 19 & $0 \cdot 20$ & $0 \frac{1}{4}$ & 59 & $\mathrm{I} \cdot 96$ & $2 \frac{1}{2}$ & 97 & $4 \cdot 8 \mathrm{I}$ & 18 \\
\hline 20 & 0.20 & I $\frac{1}{2}$ & 60 & $\mathrm{I} \cdot 96$ & 4 & 98 & $4 \cdot 8 \mathrm{I}$ & 8 \\
\hline 21 & 0.20 & 3 & $6 I$ & I·96 & 29 & 99 & $5^{\circ} 03$ & I I \\
\hline 22 & 0.20 & $0 \frac{1}{4}$ & 62 & I.96 & 5 & 100 & $5 \cdot 25$ & 78 \\
\hline 23 & 0.20 & $6 \frac{1}{2}$ & 63 & $2 \cdot 40$ & 8 & IOI & 5.47 & 2 \\
\hline 24 & 0.20 & 18 & 64 & $2 \cdot 40$ & $5 \frac{1}{2}$ & 102 & 5.47 & 3 \\
\hline 25 & 0.20 & I & 65 & $2 \cdot 40$ & I $\frac{1}{2}$ & 103 & $5 \cdot 80$ & 12 \\
\hline 26 & 0.20 & 10 & 66 & $2 \cdot 40$ & 2 & 104 & $5 \cdot 90$ & I 2 \\
\hline 27 & 0.20 & 36 & 67 & $2 \cdot 40$ & 2 & 105 & $6 \cdot 34$ & 10 \\
\hline 28 & 0.20 & 3 & 68 & $2 \cdot 40$ & 3 & I 06 & $6 \cdot 55$ & 12 \\
\hline 29 & 0.41 & $2 \frac{1}{2}$ & 69 & $2 \cdot 40$ & 6 & 107 & $6 \cdot 98$ & 5 \\
\hline 30 & $0.4^{1}$ & o $\frac{3}{4}$ & 70 & $2 \cdot 40$ & 7 & 108 & $6 \cdot 98$ & 3 \\
\hline $3^{I}$ & $0.4^{1}$ & $4 \frac{1}{4}$ & 71 & $2 \cdot 40$ & 10 & 109 & $7 \cdot 20$ & 2 \\
\hline $3^{2}$ & 0.63 & 9 & 72 & $2 \cdot 40$ & 2 & I10 & $7 \cdot 20$ & $3 \frac{1}{2}$ \\
\hline 33 & 0.63 & ot & 73 & $2 \cdot 40$ & 5 & I I I & $7 \cdot 42$ & 6 \\
\hline 34 & 0.63 & I & 74 & $2 \cdot 62$ & 13 & 112 & $7 \cdot 85$ & 5 \\
\hline 35 & 0.63 & 5 & 75 & $2 \cdot 62$ & 8 & I I 3 & $7 \cdot 85$ & 12 \\
\hline 36 & 0.63 & $2 \frac{1}{2}$ & 76 & $2 \cdot 62$ & 3 & I 14 & $8 \cdot 28$ & 72 \\
\hline 37 & 0.63 & 2 & 77 & $2 \cdot 62$ & 10 & II 5 & $8 \cdot 71$ & 12 \\
\hline $3^{8}$ & 0.63 & I & 78 & $2 \cdot 62$ & 5 & 116 & 8.71 & $3^{6}$ \\
\hline 39 & 0.63 & 3 & & & & 117 & $8 \cdot 92$ & 12 \\
\hline \multirow[t]{4}{*}{40} & 0.63 & 3 & & & & 118 & $9 \cdot 34$ & I \\
\hline & & & & & & I I9 & 10.41 & 12 \\
\hline & & & & & & 120 & $10 \cdot 60$ & 7 \\
\hline & & & & & & 121 & $10 \cdot 60$ & 84 \\
\hline
\end{tabular}

Electrophoresis

Determination of protein by the method of Lowry and others (195I) made it possible to distinguish the same groups of patients.

In the separation of the SRF proteins by means of paper electrophoresis in patients of Group I, only two fractions were discovered (albumins and globulins, the latter not being separated into their individual fractions). In Group III five fractions were found which were identical with the blood fractions when the same method was used.

However, when a more sensitive method-disc electrophoresis in acrylamide gel-was used, a difference was found: the SRF with a high protein content contained a total of seven fractions, whereas the blood contained twelve fractions. 
Table $\mathbf{V}$ Number of operations carried out and their outcome in $12 \mathrm{I}$ eyes with detachment of the retina

\begin{tabular}{|c|c|c|c|c|c|c|c|c|c|c|}
\hline \multirow[t]{2}{*}{ Group } & \multirow{2}{*}{$\begin{array}{l}\text { Total protein } \\
\text { in subretinal } \\
\text { fluid (g. per } \\
\text { cent.) }\end{array}$} & \multirow[t]{2}{*}{ No. of eyes } & \multicolumn{4}{|c|}{ No. of operations } & \multicolumn{4}{|c|}{ Outcome* } \\
\hline & & & I & 2 & 3 & 4 & ++ & +- & -- & --- \\
\hline I & Under I & 40 & $3^{6}$ & 3 & $\mathbf{I}$ & - & 30 & 6 & 4 & \\
\hline II & $\mathrm{I}-3$ & 38 & 29 & 7 & 2 & - & 17 & 14 & 5 & 2 \\
\hline III & Over 3 & 43 & 23 & 13 & 5 & 2 & 16 & 8 & 15 & 4 \\
\hline
\end{tabular}

* Outcome: ++ complete re-attachment; - - no re-attachment; +- partial re-attachment; - - - deterioration.

\section{Electrical sensitivity}

An inversely proportional relationship was found between the total SRF protein level and the threshold electrical sensitivity of the retina in eighteen out of 23 patients, i.e. in patients with a low level of SRF protein relatively high electrical sensitivity of the retina was found, whereas a high level of SRF protein was recorded in patients with a low sensitivity. Where this inversely proportional relationship was found, there was a reliable correlation (coefficient of correlation 0.88 with a total error of \pm 0.07 ). A comparatively closer link was found in patients with total detachment of the retina.

\section{Mucopolysaccharides}

The sialic acids and hexosamines were studied to discover the presence and quantitative level in the SRF of mucopolysaccharides (glucosamine glucans).

\section{Sialic acids}

These were determined in 68 SRFs taken during surgery on 65 patients.

The great variety of clinical forms of retinal detachment was reflected in the variation in the level of sialic acids in the SRF, ranging from traces to Ioo mg. per cent.

When the results obtained were arranged in increasing order of sialic acid level, we were able to distinguish the following groups of patients:

GROUP I I 4 patients ( 44 eyes)-the level of sialic acids did not exceed $15 \mathrm{mg}$. per cent.;

GROUP 22 I patients (22 eyes) - the sialic acid level was between 16 and $35 \mathrm{mg}$. per cent.;

GROUP 3 3o patients ( 32 eyes) -the sialic acid level was between 36 and $100 \mathrm{mg}$. per cent.

The most severe clinical picture was present in patients in Group 3, with a predominance of total (I9) and subtotal (7) detachments, widespread degenerative changes in the retina, pathology of the vitreous body and crystalline lens, and frequent multiple atypical giant and indeterminate tears. The severe changes in paired eyes is worthy of attention. A particularly high level of sialic acid was found in the SRF of relatively young patients with continuously progressive degenerative changes in the ocular tissues. The results of surgery in Group 3 were considerably worse than in Group I.

\section{Hexosamines}

Total hexosamines were determined in 52 SRF specimens; the pink colouration characteristics of and specific for hexosamines was found in only 32 of them (from 30 patients).

As with the other biochemical components, the level of hexosamines covered a wide range-from traces to $315 \mathrm{mg}$. per cent.

When the amount of hexosamines in the SRF was compared with the clinical indicators the same regular feature was found: a low level of hexosamines corresponded to the most favourable clinical picture and the best outcome of operation, while a high content of hexosamines occurred in severe forms of retinal detachment.

To assess the significance of the total hexosamine level, the results were compared with the other biochemical components-the sialic acids and total protein (Table VI).

It was found that, with a negligible level of hexosamines, the content of sialic acids and total protein was also low. A high level of hexosamines was usually accompanied by high concentrations of sialic acids and total protein.

\section{Duration of detachment}

Because of the contradictory reports in the literature, we examined the relationship between the biochemistry of the SRF and the duration of the lesion (Table VII).

The difference between Groups I and III proved reliable for all indices (with a magnitude of error for hexosamines and sialic acids of $\mathrm{P}=0.02$ and for total protein of $P=0 \cdot 01$ ). 
Table VI Content of hexosamines in the subretinal fluid of 32 eyes with retinal detachment compared with the level of sialic acids and total protein

\begin{tabular}{|c|c|c|c|c|c|c|c|}
\hline $\begin{array}{l}\text { Serial } \\
\text { no. }\end{array}$ & $\begin{array}{l}\text { Hexosamines } \\
\text { (mg. per } \\
\text { cent.) }\end{array}$ & $\begin{array}{l}\text { Sialic } \\
\text { acids } \\
(m g . \text { per } \\
\text { cent. })\end{array}$ & $\begin{array}{l}\text { Total } \\
\text { protein } \\
\text { (g. per } \\
\text { cent. })\end{array}$ & $\begin{array}{l}\text { Serial } \\
\text { no. }\end{array}$ & $\begin{array}{l}\text { Hexosamines } \\
\text { (mg. per } \\
\text { cent.) }\end{array}$ & $\begin{array}{l}\text { Sialic } \\
\text { acids } \\
\text { (mg. per } \\
\text { cent.) }\end{array}$ & $\begin{array}{l}\text { Total } \\
\text { protein } \\
\text { (g. per } \\
\text { cent. })\end{array}$ \\
\hline I & Io & 6 & $0 \cdot 20$ & 17 & 125 & 46 & $3 \cdot 06$ \\
\hline 2 & 20 & 4 & 0.20 & 18 & 125 & 50 & $4^{\cdot 8 I}$ \\
\hline 3 & 20 & 8 & $0 \cdot 20$ & 19 & 130 & 45 & 3.50 \\
\hline 4 & 25 & 9 & $0 \cdot 20$ & 20 & I 30 & 57 & $4^{-8} 8 \mathrm{I}$ \\
\hline 5 & 40 & 9 & $0 \cdot 20$ & $2 I$ & 135 & 48 & 5.47 \\
\hline 6 & 40 & 20 & $\mathrm{I} \cdot 30$ & 22 & 140 & 55 & $\mathrm{I} \cdot 30$ \\
\hline 7 & 47 & - & $0 \cdot 20$ & 23 & 140 & 60 & $5 \cdot 80$ \\
\hline 8 & 52 & 64 & $6 \cdot 55$ & 24 & 145 & 49 & $4 \cdot 60$ \\
\hline 9 & 52 & 40 & $7 \cdot 20$ & 25 & I 45 & 74 & 5.03 \\
\hline I0 & 70 & 27 & I.96 & 26 & $\begin{array}{l}145 \\
145\end{array}$ & 71 & 5.90 \\
\hline II & 80 & - & $4 \cdot 60$ & 27 & I5O & 90 & 3.72 \\
\hline 12 & 90 & 23 & $0 \cdot 20$ & 28 & I 50 & 80 & $4.8 \mathrm{I}$ \\
\hline 13 & 90 & 20 & $\mathrm{I} \cdot 08$ & 29 & 165 & 70 & $7 \cdot 20$ \\
\hline 14 & 90 & - & 3.06 & 30 & 200 & 100 & $6 \cdot 98$ \\
\hline 15 & 105 & $3^{I}$ & $2 \cdot 62$ & $3^{I}$ & 270 & 80 & $7 \cdot 85$ \\
\hline I6 & I IO & - & $1 \cdot 08$ & 32 & 315 & 94 & $8 \cdot 92$ \\
\hline
\end{tabular}

Table VII Mean levels of hexosamines, sialic acids, and total protein in the subretinal fuid of three groups of patients (I I I eyes) with detachments of the retina of different duration

\begin{tabular}{|c|c|c|c|c|c|c|c|c|c|c|}
\hline \multirow[t]{2}{*}{ Group } & \multirow{2}{*}{$\begin{array}{l}\text { Duration of } \\
\text { detachment } \\
\text { (mths) }\end{array}$} & \multicolumn{9}{|c|}{ Mean indices } \\
\hline & & \multicolumn{3}{|c|}{ Hexosamines } & \multicolumn{3}{|c|}{ Sialic acids } & \multicolumn{3}{|c|}{ Total protein } \\
\hline 1 & Under 2.5 & $72 \cdot 2$ & $50 \cdot 8$ & $17 \cdot 5$ & $24 \cdot 9$ & $19 \cdot 8$ & 7.5 & $I \cdot 6$ & $\mathrm{I} \cdot 6$ & 0.6 \\
\hline 2 & $2 \cdot 5$ to 9 & 113.5 & $54 \cdot 7$ & $17 \cdot 6$ & $55^{\circ} 0$ & $28 \cdot 5$ & 9.5 & $4^{\cdot I}$ & $2 \cdot 5$ & 0.8 \\
\hline 3 & Over 9 & $135 \cdot 2$ & $47 \cdot 6$ & $16 \cdot 8$ & $53 \cdot 8$ & $23 \cdot 3$ & 8.8 & $4 \cdot 5$ & $2 \cdot 3$ & 0.9 \\
\hline
\end{tabular}

The number of positive results was greatest among patients in Group I $(P=0.05)$.

When chromatographic separation of the amino sugars in the SRF was carried out, it was supposed that side-by-side with the quantitative increase in hexosamines as the clinical picture worsened, the relationship between the glucosamine-containing and galactosamine-containing sugars might change.

Hexosamines were identified on the basis of a solution of glucosamine sulphate, the peak of which was within the limit of 120 to $\mathrm{I} 60 \mathrm{ml}$. of volume of eluate. Detection of a peak within these limits in an SRF hydrolysate indicated the presence of glucosamine-containing sugars. The peak obtained in considerably later volumes of eluate- $\mathrm{r} 6$ o to $\mathrm{I} 94 \mathrm{ml}$.related to galactosamine-containing sugars.

The resilts of chromatographic separation of the amino sugars were analysed by grouping patients on the basis of protein content in the SRF on the assumption that protein is an indicator of the degree of pathological change in the eye tissues. In patients with a protein level in the SRF of under $3 \mathrm{~g}$. per cent., quite contradictory results were obtained: hexosamines were detected within the limits of the eluate of both glucosamine-containing and galactosaminecontaining sugars.

In all patients with a high protein level-over $3 \mathrm{~g}$. per cent.-uniform data were obtained: one peak within the range 162 to $196 \mathrm{ml}$. of eluate, corresponding to galactosamine-containing sugars.

It should be noted that, in a number of cases, the level of sialic acids and hexosamine in the SRF (just as with the total protein level) considerably exceeded the content of these ingredients in the blood.

\section{Discussion}

The formation of subretinal fluid is closely-linked with 
the concept of "retinal detachment", and the biochemical composition of the SRF is undoubtedly related to the pathogenesis of retinal detachment.

A comparison of the biochemical findings with the clinical picture showed that the levels of total protein, sialic acids, and hexosamines in the SRF are low in cases of retinal detachment which follow a relatively favourable course, whereas in severe cases the levels are high.

Determination of total protein showed that the minimum level was three or four times higher than that in the normal vitreous body. This does not fit in with pathogenetic theories that the SRF is formed by the liquid part of the vitreous body seeping behind the retina (Leber, I886). On the contrary, the maximum protein level in the SRF exceeded that in the blood serum. This finding also rules out the theory that the SRF is formed by blood plasma exuded from the vascular bed.

Apparently the large concentrations of total protein observed in the SRF of some patients must be ascribed to changes in the ocular tissues, especially those which form the subretinal space. This is supported by the very high level of protein which was present in cases showing the most severe forms of retinal detachment.

When we examined the question whether the level of total protein rises with the duration of the retinal detachment, we found that the group with the lowest level of protein in the SRF chiefly comprised patients with relatively recent detachments while long-standing detachments predominated among patients with a high SRF protein level; but there were numerous cases in which the protein level did not correspond to the duration of the detachment.

This finding is of great interest, in that it indicates the existence of different types of detachment which progress in different ways.

Most investigators (e.g. Heath, Beck, and Foulds, 1962; Akmeteli, 1972) believe that there is a relationship between the level of protein in the SRF and the outcome of surgery (the lower the protein level the better the outcome), but some (e.g. Sachsenweger and others, 1964) consider that the SRF protein level has no effect on prognosis.

In our opinion the SRF protein level is an indicator not so much of the duration of the retinal detachment as of the condition of the ocular tissues (which is determined by many other factors). Naturally, if the degree of pathological change is reflected in the SRF protein level, the most favourable outcome can be anticipated in patients with the lowest levels.

The determination of protein by refractometry is sufficiently reliable for comparative evaluation of the protein levels in the SRF; this method is convenient for use in the operating theatre and can be used wherever detachment surgery is practised.

As the number of fractions in SRFs with a high protein level and in the blood were the same when investigated by paper electrophoresis, some investigators (Santoni, 1954; Dorello, 1956) thought that the blood might play a role in the production of the subretinal fluid. When the protein fractions are investigated by a more sensitive method, however, there is a difference in the levels in the SRF and the blood; this does not necessarily mean that the plasma plays no part in the formation of the SRF, but it does imply that other possible sources of SRF formation should not be excluded.

Nesterov (1969) showed a certain parallelism between the clinical picture in retinal detachment and functional indices-more marked functional disturbances and in particular a sharp reduction in threshold electrical sensitivity of the retina corresponding to more severe changes in the retina. The inversely proportional relationship between the SRF protein level and the electrical sensitivity of the retina confirms that the high concentrations of protein in severe forms of retinal detachment are directly related to these disturbances (Nesterov and Akhmeteli, r97 I).

Not much information is available regarding the presence of sialic acids in the ocular tissues in health and disease. According to Haddad and Becker (196r), the largest amount is found in the corneal stroma -57 per cent. (as compared with the blood serum taken as roo per cent.), in the crystalline lens (without the capsule) -30.7 per cent., and in the retina-23.7 per cent. In the aqueous humour and the anterior and posterior vitreous body in the normal human eye, the corresponding percentages are only $6 \cdot 0,3.5$, and $7 \cdot$ I per cent. The content of sialic acids in the anterior layers of the retina was roughly onethird of the amount contained in the posterior layers; the authors suggest that this may be due to the presence of nerve tissue in this part of the retina.

When Haddad and Becker (196I) investigated the sialic acids in the SRF of twelve eyes with retinal detachment, they noted an increased level in cases of cystic degeneration of the retina and retinoschisis; this led them to suggest that these acids may be an important factor in degenerative processes in the retina.

According to our data, a high level of sialic acids in the SRF accompanies an unfavourable clinical course of retinal detachment, both in the retina and other ocular membranes. The high levels of sialic acids found in the SRF did not fit in with present concepts of the pathogenesis of retinal detachment. If the SRF is mainly a consequence of the penetration of the vitreous body (containing very small amounts of sialic acids) through a tear into the subretinal space, the source of the high concentrations found in our patients is not clear; nor is it clear how the sialic acid level increases as the lesion develops. Moreover, the concentration of sialic acids is much higher in the SRF than in the blood. 
Very little has been published about the hexosamines in the SRF in retinal detachments. Richter and Vetter (1964) found a high concentration, twice as high as that in the blood, and in two cases of fresh detachment, the hexosamine level proved to be particularly high. They ascribed this to the participation of the vitreous body in the formation of the subretinal fluid, since according to Schweer (1962) the vitreous body proteins contain about 5 per cent. hexosamines and the serum proteins only $\mathrm{I} \cdot 5$ per cent.

We found a high hexosamine level in severe forms of retinal detachment, especially in individual cases with profound disturbances of the ocular membranes. In many instances the hexosamine level in the SRF considerably exceeded that in the blood.

Thus an increase in the concentration of hexosamines in the SRF like the increases in total protein and sialic acids, usually occurred as the clinical symptoms worsened. The level of hexosamines (and of other biochemical components) is therefore an indicator of the severity of the disorder, but in exceptional cases different combinations are found.

A comparison of biochemical and clinical investigations shows that disturbances in biochemical interrelationships give a clue to the primary cause of the formation of the SRF.

\section{Summary}

The level of total protein, protein fractions, sialic acids, and hexosamines was studied in the subretinal fluid (SRF) and blood of patients with retinal detachment. The level of these components in the SRF varied over a considerable range. A low level of total protein, sialic acids, and hexosamines was characteristic of patients with relatively recent clinical forms of retinal detachment, following the most favourable course, and with the best response to surgery. Higher indices were found in patients with marked changes in the fundus oculi, gross destruction of the vitreous body, considerable pathology of the crystalline lens, and correspondingly worse response to surgery.

As the pathological changes develop in retinal detachment, there is a parallel increase in the protein levels in the SRF. However, exceptions to this rule indicate that the pathological process may vary.

An inverse correlation is found between the level of total protein in the SRF and the electrical sensitivity of the retina.

A comparison of the biochemical investigation with the clinical examination suggests that the occurrence of retinal tears and the increase of protein in the SRF are due to the same degenerative processes.

\section{References}

AKHMEteli, L. M. (1972) "Biochemical investigation of the subretinal fluid in retinal detachment". Thesis, Moscow.

ARRUGA, H. (1933) "XIV Concilium Ophthalmologicum, Hispania", vol. 2, p. 5

Chignell, A. H., GARRUthers, M., and RAHI, A. H. s. (I97I) Brit. F. Ophthal., 55, 525

COOPER, W. c., HALBERT, s. P., and MANSKI, w. J. (I963) Invest. Ophthal., 2, 369

DORELlo, U. (1956) Amer. F. Ophthal., 4I, 564

FOJUDZKI, E., and KALUZNY, J. (1969) Klin. Oczna, 39, 8I 3

GARDELL, s. (1953) Acta chem. scand., 7, 207

GRABAR, P., and Williams, C. A. (1953) Biochim. biophys. Acta, ro, I93

HADDAD, H. M., and BECKER, B. (1961) A.M.A. Arch. Ophthal., 65, 563

HEATH, H., BECK, T. C., and FOULDs, w. s. (1962) Brit. F. Ophthal., 46, 385

Kuzina, N. I. (1968) Vop. med. Khim., I4, pt. I, p. 58

LEBER, T. (1886) Ber. Versamm. Ophthal. Ges. Heidelberg, 18, 45 (Discussion of paper by Stilling)

LOWRY, O. H., ROSEBroUgh, N. J., FARR, A. L., and RANDALl, R. J. (I95I) 7. biol. Chem., 193, 265

MAGITOT, A., and LENOIR, A. (1932) Bull. Soc. frang. Ophtal., 45, 225

NESTERov, S. A. (1969) "Functional Investigations of the Eye in Retinal Detachment". Thesis, Moscow

and AKHMETELI, L. M. (I97I) In "Trans. 29th Scientific Session of the Helmholtz Institute on Path-

ology of the Retina and the Optic Nerve", Moscow, pp. 25-27

Richter, s., and VETTER, K. (1964) v. Graefes Arch. Ophthal., 167, 145

RONDLE, C. J., and MORGAN, w. T. J. (1955) Biochem. F., 6I, 586

SAGHSENWEGER, R., GASSLER, H., and HENTSCH, R. (1964) v. Graefes Arch. Ophthal., 166, $43^{2}$

SANTONI, A. (I954) G. ital. Oftal., 7, 289

SCHEIDEGGER, J. J. (1955) Int. Arch. Allergy, 7, 103

SCHENK, H., FORMANEK, K., and FÖRSTER, O. (196I) v. Graefes Arch. Ophthal., I64, 29

$\longrightarrow$ - -

SCHWEER, G. (1962) "Glaskörper und Hyaluronsäure-Hyaluronidase System". Thieme, Leipzig

SEMENOVSKAJA, E. N., and BoGosLOVSKIJ, A. I. (1960) "A complex method of electrophysiological investigation

of the visual functions in clinical ophthalmology", in "Documentation of the Second All-Union Conference

of Innovators and Rationalizers in Ophthalmology, Moscow, 1960", pp. I4-15

sMith, J. L., and Douty, A. (1960) A.M.A. Arch. Ophthal., 64, I 14

SVENNERHOLM, L. (1957) Biochim. biophys. Acta, 24, 604

WEVE, H. J. M., and FISCHER, F. P. (1940) Ophthalmologica (Basel), 99, 29I 